\title{
Measuring Overtourism: A Necessary Tool for Landscape Planning
}

\author{
Eva M. Buitrago ${ }^{1}$ (D) and Rocío Yñiguez ${ }^{2, *}$ \\ 1 Department of Applied Economics III, University of Seville, 41018 Seville, Spain; esquinas@us.es \\ 2 Department of Economic Analysis and Political Economy, University of Seville, 41018 Seville, Spain \\ * Correspondence: ovando@us.es; Tel.: +34-954558465
}

Citation: Buitrago, E.M.; Yñiguez, R. Measuring Overtourism: A Necessary Tool for Landscape Planning. Land 2021, 10, 889. https://doi.org/ $10.3390 /$ land 10090889

Academic Editor: Luís Carlos Loures

Received: 29 July 2021

Accepted: 19 August 2021

Published: 25 August 2021

Publisher's Note: MDPI stays neutral with regard to jurisdictional claims in published maps and institutional affiliations.

Copyright: (c) 2021 by the authors. Licensee MDPI, Basel, Switzerland. This article is an open access article distributed under the terms and conditions of the Creative Commons Attribution (CC BY) license (https:// creativecommons.org/licenses/by/ $4.0 /)$.

\begin{abstract}
The tourism debate prior to the COVID-19 pandemic was dominated by the problems inherent in overtourism, reflecting an inadequate land management. Although publications on overtourism have grown exponentially in recent years, its scientific study still has major shortcomings, particularly with regard to measurement. With the aim of overcoming this insufficiency, we have carried out a review of the literature (using the mapping review method) and, based on its conclusions, we have drawn up a proposal to systematise the measurement of overtourism by combining several tools: indicators, surveys, interviews, and other tools linked to the Internet and social networks. The results of the research make a contribution to the expansion of the literature on the topic and may have important practical implications in formulating effective land-use policies by guiding policy makers in the management of overtourism. They could be of use in both the early detection of overtourism and the design of policies that prevent and/or detect situations of risk and that correct existing problems. This is especially relevant in the current international context to implement the effective transition to a responsible tourism model post-COVID-19.
\end{abstract}

Keywords: overtourism; indicators; surveys; interviews; social media; land planning

\section{Introduction}

Overtourism is a recent term used by academics, industry professionals, and policy makers to cover some of the problems of the pre-COVID-19 tourism model suffered by many destinations, especially in urban contexts [1,2]. In recent decades, the rapid development of ICT and globalisation have changed both ways of travelling and business models. Tourist numbers have grown exponentially, converging in certain places at certain times; this has generated land-use conflicts and situations of overcrowding which are damaging both the quality of life of the local residents and the satisfaction of tourists, as well as the environment in which it takes place [3]. UNWTO defines overtourism as "the impact of tourism on a destination, or parts thereof, that excessively influences perceived quality of life of citizens and/or quality of visitors' experiences in a negative way. (... ) It is the opposite of Responsible Tourism, which is about using tourism to make better places to live in and better places to visit" [1] (p. 4).

Although, in recent years, overtourism has become a buzzword [4], with a major growth in publications analysing it, its scientific study still suffers from some relevant shortcomings, mainly in terms of measurement $[2,5,6]$. Overtourism, literally an excess of tourism, has implicit quantitative aspects in its definition which should be measured in order to carry out rigorous analyses. However, most of the literature either do not include any element of measurement, or do so only partially and indirectly $[7,8]$. There are no widely accepted methodologies for the measurement of overtourism that allow diagnoses or comparisons between different destinations. Thus, the following questions still remain open: What factors should be measured to approximate the existence of overtourism? What are the most appropriate tools to measure each of these factors? Is it possible to calculate limits or thresholds from which the existence of overtourism can be stated? If the 
factors and/or tools chosen are not adequate, mistaken conclusions could be reached. Let's observe it through an example of two of the most visited tourist cities in Spain: Madrid and Barcelona, for 2019 (2019 data are used in order to avoid distortions that COVID-19 has generated in tourism data of 2020) [9]). Considering only the number of visitors in hotel establishments, the situation in Madrid seems more serious than in Barcelona (10 and 8.5 million annual visitors, respectively). However, if these data are relativised considering the population of each city, the results change completely: the ratio of visitors per inhabitant is 5.21 in Barcelona, while, in Madrid, it is 3.05. This explains why Barcelona is one of the most cited examples of overtourism in the literature $[7,8]$, and that there is a growing number of anti-tourist movements in the city [10]. Thus, the opinion of $61.3 \%$ of residents in Barcelona is that the admissible limit of tourists has been reached (this percentage increases to $84.1 \%$ in the most touristy neighbourhoods) [11].

This paper deals with the measurement of overtourism. In order to overcome the above-mentioned shortfall, we have set ourselves the objective of making a proposal for the systematisation of the measurement of overtourism that will be able to guide both future research work and the formulation of spatial planning policies.

In order to assess the progress made in this topic, we have carried out a review of the scientific literature using the mapping review method to determine the sources used to measure overtourism and to extract the main weaknesses and strengths of current overtourism measurement. Based on the conclusions of this review, we developed a measurement proposal to guide us along the road ahead.

Thus, a double contribution is made. Firstly, it enriches the previous literature by helping to overcome the existing shortfall in the measurement of overtourism. As far as we know, there are no works that have exhaustively analysed how overtourism has been measured or that systematise a complete proposal to measure the different dimensions of overtourism. Secondly, the conclusions of this work may have important practical implications in formulating effective land-use policies by guiding policy makers in the management of overtourism. They will be able to contribute to both the early detection of the symptoms of overtourism and the design of policies that prevent and/or detect situations of risk and that correct existing problems. All of the above are especially relevant in the current international context. The crisis caused by COVID-19 has dealt a major blow to tourism. However, the "halt" in activity and the changes in the attitudes and behaviour of tourists, stakeholders, and governments can and should be used to rethink the tourism model that is pursued in the future, avoiding the pitfalls of the past [12]. The real challenge for the post-COVID-19 era is not when tourism will return, but how it will return. Nowadays, the transition towards a responsible tourism model is no longer an option, but has become a necessity [6]. In this respect, having the right measurement tools can be decisive. Tourism research has, today more than ever, the mission of guiding this transition.

This paper is structured as follows: this introduction is followed by the description of the research method and sample profile; Section 3 presents and discusses the results of the literature review; a proposal for the measurement of overtourism is made in Section 4; and, lastly, a set of concluding remarks is laid out in Section 5.

\section{Methodological Approach and Data}

A mapping review method has been carried out to study the literature on measurement of overtourism. This method has been developed by the EPPI-Centre of the Institute of Education (London) to map out and categorise existing literature on a particular topic, identifying gaps in research literature [13]. The bibliographic research was carried out using the method of systematic mapping of the literature, which consists of categorising the existing literature and considering qualitative and quantitative aspects.

Data for the mapping review were collected using purposive sampling to select relevant papers on overtourism. The search for these studies was conducted in the Web of Science and Science Direct. The search was then completed with Google Scholar. The 
keywords used were different forms of expressing "overtourism" (overtourism, over tourism, overcrowding, carrying capacity, mass tourism), and the search period was from 1990 to early 2020. Due to the multidisciplinary character of overtourism, the search tackled various areas of knowledge, such as sociology, geography, economics, politics, ecology, and psychology.

The first search returned around 200articles. After excluding duplicate documents and previous versions of the same work, 99 unique studies were selected.

The initial sample was coded according to the following dimensions: the identification of the work (author and year); treatment of overtourism (direct or indirect); type of paper (theoretical, empirical, critical, opinion, report, review); tourist typology (city, coast, events, heritage, rural); and geographical area (continent and specific geographical tourist destination). A summary of the information from all the studies is available as Supplementary Material.

In keeping with the goal of this paper, the final sample was achieved, taking into account whether the work included elements of measurement or not, and distinguishing whether the measurement was general or specific to ascertain the degree of overtourism. Moreover, in the papers in which overtourism is measured, several fields were added to identify the measurement tools used: indicators, surveys, interviews, and social media. For each of these tools, fields have been included to categorise the measurement: authorship, type, recipients, and methodological aspects.

Of the 99 papers initially selected, only $38 \%$ include measurements related to overtourism, and only $26 \%$ measure it directly. Moreover, most of them quantify partial aspects of overtourism. This confirms the shortcomings in overtourism measurement and, thus, the relevance of this research.

Although the articles reviewed were published during the period 1992-2019, between $90 \%$ and $100 \%$ of the papers that include measurements of overtourism have been published in the last 4 years. These data confirm that studies on overtourism are recent, especially those that include measurements of the phenomenon analysed (Figure 1).

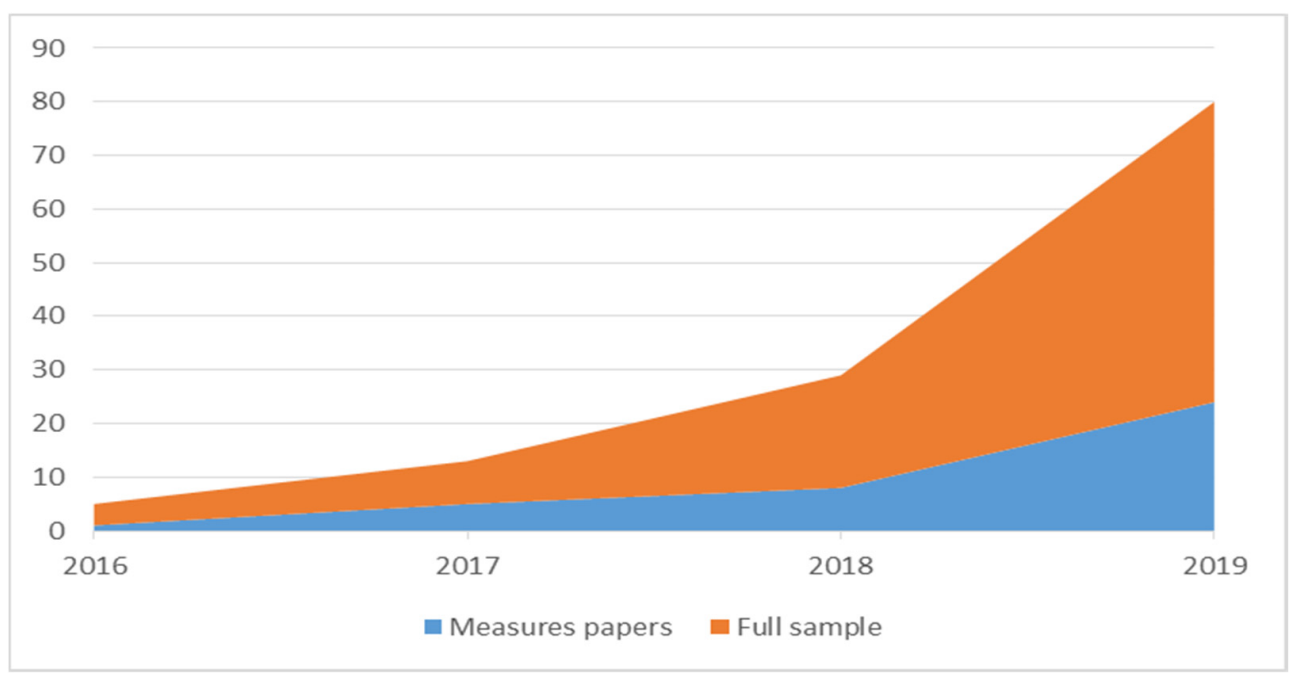

Figure 1. Trends in overtourism publications: papers with measurements vs. full sample.

On the other hand, most of the studies that deal with overtourism are case studies of specific cities (40\%), which confirms that it is a phenomenon that mainly affects urban destinations (see Figure S1 in Supplementary Material).

The main measurement tools used in the 38 papers that quantify overtourism are: indicators (24 papers), surveys (20 papers), interviews (17 papers), and measurements associated with social networks (6 papers). The majority of these papers combine several of these tools to explore the measurement of aspects linked to overtourism (Figure 2). 


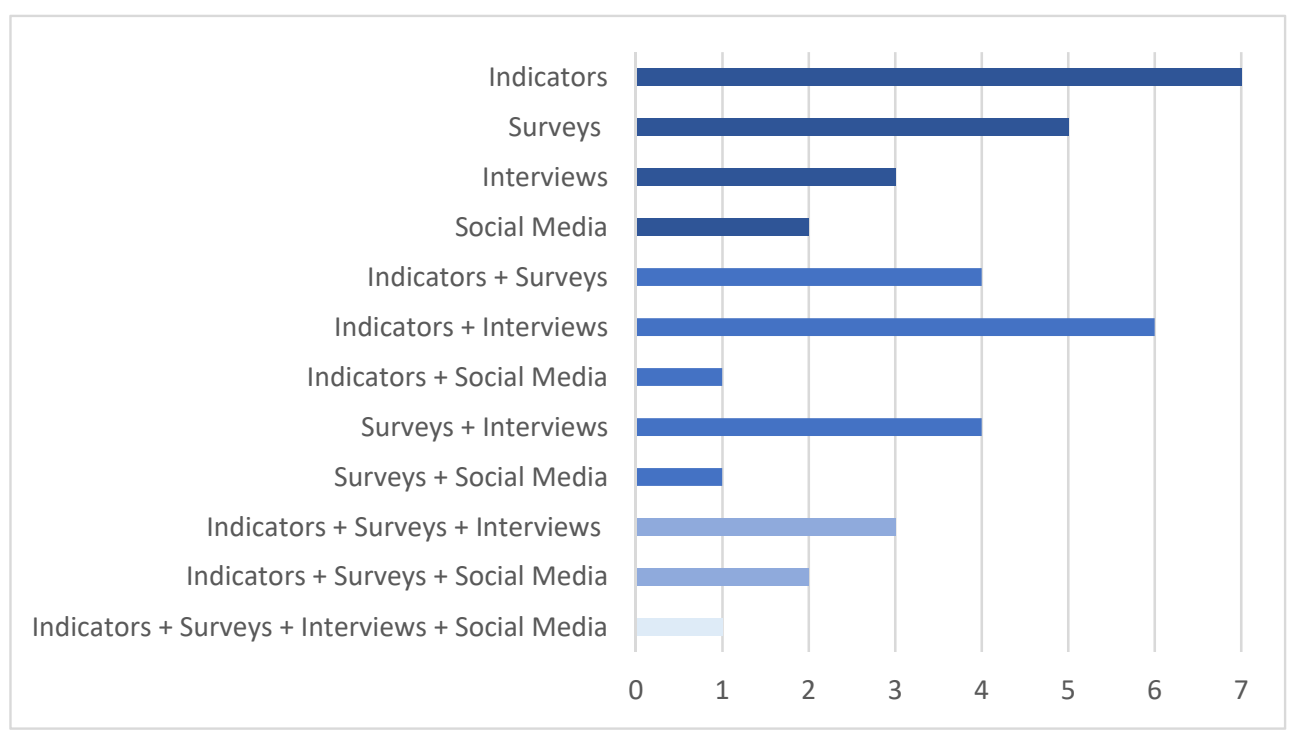

Figure 2. Overtourism measurement tools in literature.

Given the objectives of this research, we focused on the analysis of the 38 documents that quantify overtourism (18 focus on the analysis of urban destinations). We made an initial classification based on the measurement tools used and carried out an in-depth analysis of the documents in order to determine the strengths and weaknesses of each tool in measuring overtourism (Section 3). Based on the conclusions obtained, in Section 4, we set out a proposal for the measurement of the different dimensions of overtourism.

\section{Measuring Overtourism: Literature Review}

\subsection{Indicators for Measuring Overtourism}

Once the 24 papers that include indicators had been identified, we codified the basic aspects of these indicators in order to analyse them in depth (see Supplementary Material). We carried out an initial codification according to the authorship of the indicators by distinguishing works that create their own indicators, those that calculate using existing indicators for the area under consideration, and those that simply cite data from indicators that have already been published. We then codified according to the type of indicator. On the one hand, we found a set of indicators constructed solely from variables linked to tourism activity, which we called absolute tourism indicators. On the other hand, we identified the indicators which relate tourism variables to other general variables within a geographical area, society, or economy where the activity takes place: relative tourism indicators. For both types of indicators, we distinguished those which quantify aspects of demand, aspects of supply, economic aspects, or constructed composite indicators combining several of these dimensions. In addition, we codified whether the growth rates of the indicator are analysed or whether it is spatially or temporally disaggregated. Finally, we identified the studies that establish some kind of threshold or reference point of the indicators proposed with which to evaluate overtourism.

Half of the papers analysed only use indicators to contextualise their research. These papers limit themselves exclusively to reproducing a set of absolute tourism indicators for the area under analysis, which was, in no case, of their own creation or specific to the measurement of overtourism. Furthermore, they do not include growth rates or carry out spatial or temporal disaggregation. Given that it is not possible to diagnose overtourism on the basis of these indicators, this section focuses on a detailed analysis of the papers which calculate relative tourism indicators. Relative indicators, by relating the tourism dimensions with variables linked to the population and the territory where the tourist activity takes place, do allow approximation of the existence of overtourism. 
In Table 1, we have gathered the papers that include indicators, classifying those that are useful for the measurement of overtourism (relative indicators) and indicating the destination/s which they are used to evaluate. We classified the relative indicators of both supply and demand into indicators of tourism intensity and indicators of tourism density, depending on whether they have been used to relativise variables in relation to population or surface area. Additionally, we included other indices which are useful to ascertain overtourism.

Table 1. Measuring overtourism through indicators: literature review.

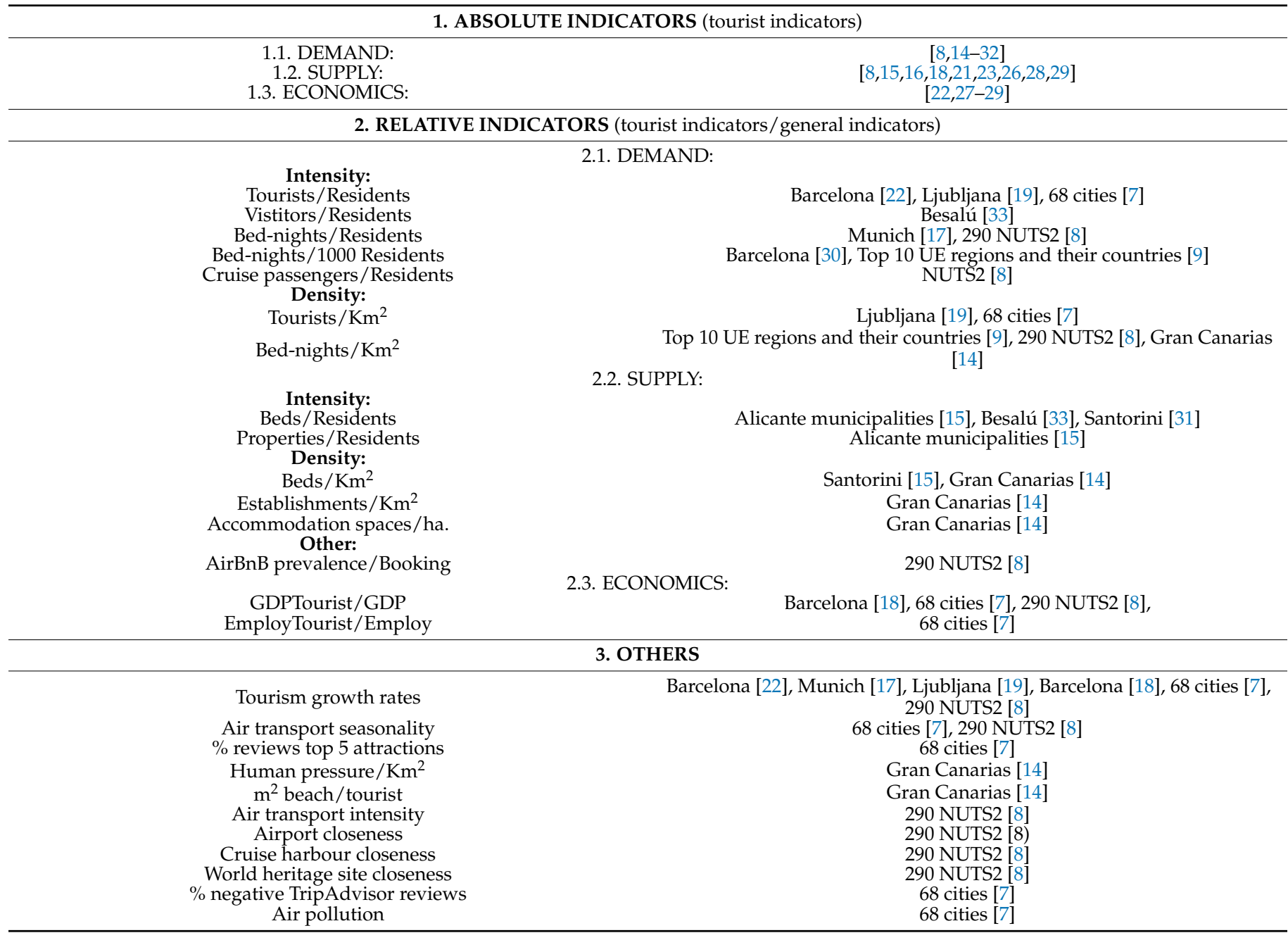

Note: the numbers in parentheses correspond to the code of the references.

There are few papers which have created specific indicators to measure overtourism $[7,8,14]$. The remaining papers either apply existing indicators to their area or simply reflect already published data.

Secondly, most papers focus on a single destination, which makes comparisons difficult. The exceptions are the reports by McKinsey and WTTC [7], and Peeters et al. [8]. These studies were carried out with the aim of providing key indicators that could serve as an early warning mechanism for the detection of overtourism. Although both reports agree that overtourism is a complex phenomenon and that it is not possible to find onesize-fits-all recipes for all destinations, McKinsey and WTTC [7] calculate nine indicators for 68 cities with overtourism symptoms, and Peeters et al. [8] calculate eight indicators for 290 NUTS2 of the EU (regions with and without overtourism symptoms).

Thirdly, regarding the typology of indicators, the papers analysed mostly include relative indicators of demand, both in terms of tourism intensity and density. The main 
problem detected is that individual studies use different calculation formulas. The following are used indistinctly: the number of tourists (total or international tourists), the number of visitors or overnight stays. To calculate tourism intensity, on some occasions, the total ratio per resident is given and, on others, the number per 1000 inhabitants (this is Eurostat's chosen ratio, included in Papathanassis [10]). In the calculation of tourism density, although the square kilometres of the area under consideration is the most common method, McKinsey and WTTC [7] use the area in which, according to TripAdvisor, the 20 main attractions of the destination are located. Furthermore, these indicators are not named in the same way in all the papers. In some cases, intensity and density of tourism are confused. Although these are the main relative indicators of demand, there are studies which calculate other indicators that can also be used to measure the pressure of tourism demand (e.g., Peeters et al. [8] calculate the cruise intensity).

Studies that include relative indicators of supply also use tourism intensity and density indices. In these cases, there is also no homogeneity in their calculation. In order to calculate accommodation density, some use the number of establishments or the square metres of the buildings, and others the number of beds. Other works calculate beds per resident, but do not name the index in the same way: Muler et al. [33] speak of the tourism function index and Baños et al. [15] of the tourism specialisation index. Although most focus on the supply of regulated accommodation, some papers have also calculated the supply of unregulated accommodation and second homes [14,31]. To ascertain the pressure of second homes, Carballo et al. [16] calculate the ratio between the total number of properties and the resident population. Finally, Peeters et al. [8] calculate the ratio between Airbnb beds and total number of beds offered by Booking to measure the pressure of this accommodation, which has been typified as one of the causes of overtourism in many destinations.

Papers that include relative economic indicators are scarcer. However, there is agreement on the variables chosen and on the calculation formula: percentage of tourism GDP or tourism employment over total GDP or employment. With economic indicators, the problem lies in the availability of data, as it is difficult to find information on the GDP generated by tourism below the national level.

Moreover, some of these papers combine relative indicators with other indicators that are linked to the defining elements, causes, or consequences of overtourism. Concentration of demand is calculated by dividing the reviews on TripAdvisor of the top five attractions by the reviews of all attractions [7]. To ascertain the impact on the area, Simancas and Peñarubia [14] calculate human pressure, the square metres of beach per tourist, and the percentage of built-up land. In addition, other indicators which are linked to the causes of overtourism can be useful in predicting the risk of the phenomenon occurring: air transport intensity, airport and/or cruise harbour proximity, and world heritage site proximity [8]. Other indicators are related to consequences: share of negative reviews among TripAdvisor's top 10 attractions of the destination, or air pollution [7].

Most of the indicators reviewed have been calculated on the basis of global data for the whole of the area in question over a whole year. Neither spatial nor temporal disaggregation has been carried out, which makes it difficult to measure overtourism, as this is a phenomenon which normally converges in time and place. The only exceptions are McKinsey and WTTC [7] and Peeters et al. [8], who calculate seasonality indicators; and Kagermeier and Erdmenger [17], Martin et al. [18], Muler et al. [33], and Simancas and Peñarubia [12], who carry out spatial disaggregation in the areas under consideration.

Finally, few studies establish thresholds for indicators that can serve as a warning mechanism for the existence of overtourism. Of particular note are the two reports by McKinsey and WTTC [7] and Peeters et al. [8], which determine different levels of risk of overtourism based on the comparison of indicators calculated in different destinations. McKinsey and WTTC [7] break down the nine indicators of the 68 cities into quintiles that indicate the relative risk of experiencing overcrowding, and then they draw up risk diagrams for each city. Peeters et al. [8] proceeds in a similar way for the 290 NUTS regions, dividing the results of their eight indicators into five percentiles and drawing a heat map 
with the average for each indicator. The results differ from those obtained by McKinsey and WTTC [7] because the scale is different (cities versus regions) and because the comparison of Peeters et al. [8] includes both regions with and without overtourism. Alternatively, the work of Simancas and Peñarubia [14] includes the thresholds of maximum permitted gross accommodation density established in territorial planning laws.

The remaining papers do not set specific thresholds, at best providing data from other destinations with which to make comparisons $[17,18,33]$, or use the risk thresholds from the reports discussed above [19]. However, these comparisons are complex, as each destination is unique and the spatial scales are different. A tourism demand intensity ratio calculated at a national level is not the same as one calculated for a city or even a district, and neither is it the same to analyse a large city as a small town. Furthermore, the type of tourism and the vulnerability of the destination can greatly influence the thresholds.

\subsection{Surveys for Measuring Overtourism}

The papers that include surveys have been codified considering: target groups, authorship, methodology used, and whether or not they include thresholds for the detection of overtourism. The surveys which feature more prominently are those carried out on residents, followed by those undertaken with tourists. Most of the surveys analysed were designed ad hoc by the authors of the papers or adapted in accordance with the specific objectives of the research.

Although there is great heterogeneity in the questionnaires and samples, we have grouped the items according to their objective: (1) ascertaining the perception of residents and/or tourists on the impacts of tourism; (2) ascertaining their attitude and behaviour towards the sector; (3) ascertaining their opinion on various aspects of tourism management in the destination; and/or (4) ascertaining tourist satisfaction. In Table 2, we have organised the papers according to the respondents and the structure of the questionnaires, indicating where the surveys were carried out. Most of the questionnaires include items from several blocks; this allows for an indirect approximation of the presence of overtourism.

Table 2. Measuring overtourism through surveys: literature review.

\begin{tabular}{|c|c|c|}
\hline QUESTIONNAIRE (Items) & RESIDENTS & TOURISTS \\
\hline (1) Perceptions & \multirow{3}{*}{$\begin{array}{c}\text { Porto [20], Mallorca [21], } 6 \text { Cities [2], Ljubljana } \\
\text { [19], Barcelona [18], Besalú [33], Bled [30] } \\
\text { Barcelona [22], Arzachena [32], Mallorca [21] }\end{array}$} & \multirow[b]{4}{*}{ Norway-cruises- $[34,35]$, China [36] } \\
\hline Economic, Social, Environmental impacts & & \\
\hline Global impacts & & \\
\hline $\begin{array}{l}\text { Overcrowding perception } \\
\text { (2) Attitudes and Behaviour }\end{array}$ & & \\
\hline & Barcelona [22], Porto [20], Mallorca [21], & \\
\hline Attitudes towards future tourist development & $\begin{array}{c}\text { Munich [17], } 6 \text { Cities [2], Ljubljana [19], Besalú } \\
\text { [33], Munich [23], Budapest [37,38] }\end{array}$ & Munich [17], Budapest [37-39] \\
\hline Feelings towards tourists & \multirow{4}{*}{$\begin{array}{c}\text { Hong Kong [24], Munich [17,23], Budapest [36] } \\
\text { Porto [20], Munich [17,23], 6 Cities [2], } \\
\text { Ljubljana [19], } \\
\text { Porto [20], Arzachena [32], Munich [17],6 } \\
\text { Cities [2], Ljubljana [19], Budapest [37] }\end{array}$} & Munich [17], Budapest [37] \\
\hline Behavioural response & & Munich [17] \\
\hline $\begin{array}{c}\text { (3) Opinion (Support for strategies to deal with } \\
\text { tourism development) }\end{array}$ & & \multirow{2}{*}{$\begin{array}{c}\text { Budapest [37] } \\
\text { Ontario-beaches- [40], Norway-cruises- } \\
{[34,35], \text { China [36] }}\end{array}$} \\
\hline (4) Tourist Satisfaction & & \\
\hline OTHER (Segmentation elements) & \multirow{4}{*}{$\begin{array}{c}\text { Porto [20], Arzachena [32], 6 Cities [2] } \\
\text { Barcelona [18,22] Arzachena [32], } 6 \text { Cities [2], } \\
\text { Bled [30] } \\
\text { Arzachena [32], 6 Cities [2], Barcelona [18], } \\
\text { Besalú [33], Bled [30] }\end{array}$} & \\
\hline Community attachment & & \\
\hline Area of residency & & \\
\hline Relationship to tourist activity & & \\
\hline
\end{tabular}

Note: the numbers in parentheses correspond to the code of the references.

1. Here, the items used to measure the perception of the impacts of tourism are structured into economic, social, and environmental impacts [2,18-21,30,33]. Most questionnaires provide an extensive list of possible positive and negative impacts in each of the three areas to which the respondent expresses his/her degree of agreement or disagreement about their perception of the levels of these within their territory. The work of Martin et al. [18] is noteworthy in that it records impacts in a neutral way and 
it is the respondent who classifies them as positive or negative according to their experience. Other questionnaires ask about negative impacts using open-ended questions [17] or include final items to globally assess the impact of the activity on the destination [22,32].

2. The items used to measure the attitude and behaviour of respondents towards the sector are highly heterogeneous. Despite this, we were able to organise them into three groups. The first group measures residents' attitudes towards the future of the sector, asking them whether limits should be set $[2,19,20]$, and whether the desirable limit has been reached or exceeded $[17,22,24]$. The second group measures residents' feelings towards tourists by asking about the level of "annoyance" tourists generate $[23,24,37]$ and how this makes residents feel [17]. The third group is used to measure residents' responses to tourism, including questions about how residents react to their encounters (especially negative ones) with tourists: whether they accept or avoid them [17], whether and how they change their habits [2,20], and even whether they have thought about changing their place of residence [19].

3. The opinions questionnaire includes items related to how tourism is being managed in particular destinations and which measures have the highest support $[2,17,20,37]$, as well as the level of resident participation in tourism management [19,32].

4. Finally, the questionnaires aimed towards ascertaining tourist satisfaction use items linked to tourists' perception of overcrowding, their feelings about it, or their overall satisfaction with their trip [34-36,40].

In the studies analysed, the existence of overtourism can be explored indirectly through the responses to the items in these four blocks. The items which are most closely linked to overtourism are those in the second block, particularly those which ask whether the limit of the number of tourists that the destination can sustainably absorb has been reached. The work of Koens et al. [2] is noteworthy, as it focuses its questionnaire on critical encounters between residents and tourists, analysing the reactions to these encounters and how they impact on the attitude towards tourist development.

In addition to the above, the main shortcomings in measuring overtourism that we have detected in the surveys are related to the samples selected and the segmentation of the results. On the one hand, there is great variability in the size and composition of the samples, which makes comparison difficult. On the other hand, there are few studies that segment the results by other means than their socioeconomic aspects. Although the perceptions, attitudes, and opinions of residents about tourism activity are influenced by variables such as the feeling of belonging to the destination, the proximity of the neighbourhood to the tourist centres, or whether there is a direct relationship with tourism, most studies do not include them in their analyses (see Table 2). Likewise, only Gutierrez-Taño et al. [21], Martin et al. [18], and Namberger et al. [23] break down the results according to elements linked to the type of tourism received, which would allow for an assessment of possible fields of conflict.

\subsection{Interviews to Measure Overtourism}

In total, 17 studies include interviews through which overtourism can be explored, although, for the most part, indirectly. These interviews were carried out with the aim of discovering the perceptions, attitudes, and opinions of the stakeholders as a whole. As shown in Table 3, a common feature is their holistic approach: they combine different respondents, different topics, and methodologies; moreover, these works combine interviews with other tools. The interview is often the tool of choice for determining the general perceptions, attitudes, and opinions of stakeholders and residents, with very little attention being paid to interviewing tourists. 
Table 3. Measuring overtourism through interviews: literature review.

\begin{tabular}{|c|c|c|c|c|c|}
\hline \multicolumn{6}{|c|}{ TARGET GROUPS } \\
\hline \multicolumn{2}{|c|}{ Tourist } & \multicolumn{3}{|c|}{ Residents } & Stakeholders * \\
\hline Alaçatı [26], C & 6], Budapest [37] & \multicolumn{3}{|c|}{$\begin{array}{c}\text { Isle of Man [25], Barcelona [18,39,41], Alaçatı [26], } 13 \text { cities [2], Besalú } \\
\text { [33], Budapest [37], Australia [42] }\end{array}$} & $\begin{array}{c}\text { London [43], Antaya } \\
\text { [29], Isle of Man [25], } \\
\text { Australia [42], Alaçat1 } \\
\text { [26], Munich [17], 13 } \\
\text { cities [2], Africa [27], } \\
\text { Besalú [33], Budapest } \\
\text { [37], Bled [30], } \\
\text { Kraków [28] }\end{array}$ \\
\hline \multicolumn{6}{|c|}{ ISSUES } \\
\hline \multicolumn{2}{|c|}{ Perceptions } & \multicolumn{3}{|c|}{ Attitudes } & Opinion \\
\hline $\begin{array}{r}\text { Antaya [29], Isle } \\
\text { Alaçat1 [26], Mur } \\
\text { [27], London [43], } \\
\text { [33], Budapest [ }\end{array}$ & $\begin{array}{l}\text { [25], Australia [42], } \\
\text { ], } 13 \text { cities [2], Africa } \\
\text { ona [18,39,41], Besalú } \\
\text { d [30], Kraków [28] }\end{array}$ & \multicolumn{3}{|c|}{$\begin{array}{c}\text { Antaya [29], Isle of Man [25], Australia [42], Alaçatı [26], London [43], } \\
\text { Barcelona [39,41] }\end{array}$} & $\begin{array}{c}\text { Isle of Man [25], } \\
\text { Australia [42], Alaçat1 } \\
\text { [26], } 13 \text { cities [2], } \\
\text { Africa [27], London } \\
\text { [43], Barcelona } \\
\text { [39,41], Kraków [28] }\end{array}$ \\
\hline \multicolumn{6}{|c|}{ METHODOLOGICAL ELEMENTS } \\
\hline \multicolumn{3}{|c|}{$\begin{array}{c}\text { Isle of Man [25], Australia [42], Alaçatı [26], } \\
\text { Munich [17], China [36], Africa [27],'London } \\
\text { [43], Barcelona [18,41], Besalú [33], Budapest } \\
\text { [37], Bled [30], Kraków [28] }\end{array}$} & Descriptive & \multicolumn{2}{|c|}{$\begin{array}{l}\text { Antaya [29], Alaçatı [26], Munich [17], } 13 \text { cities } \\
\text { [2], Africa [27], Barcelona [18,39,41], Besalú } \\
\text { [33], Budapest [37], Bled [30], Kraków [28] }\end{array}$} \\
\hline Group & \multicolumn{2}{|c|}{ Antaya [29], 13 cities [2], Barcelona [39] } & Others & \multicolumn{2}{|c|}{$\begin{array}{c}\text { Isle of Man [25], Australia [42], China [36], } \\
\text { London [43] }\end{array}$} \\
\hline
\end{tabular}

Note: the numbers in parentheses correspond to the code of the references. ${ }^{*}$ Stakeholders Include: suppliers, policy makers, experts and others.

Although many of the interviews analysed include questions about perceptions, attitudes, and opinions $[25,26,39,41-43]$, they are often used primarily to ascertain views about management policies that are being undertaken or may be implemented $[25,27,28,44]$. Very few interviews include explicit questions about the existence and/or dimension of overtourism in the territory (Akbulut and Ekin [29], from the NGO perspective; Liu and Ma [36], from the tourist perspective).

There is considerable methodological diversity, both in the way the interviews were carried out and in the techniques used for their analysis, with a prominent use of semistructured and individual interviews and descriptive analyses. In addition, many studies combine interviews with other qualitative and/or quantitative tools in order to achieve more solid results by making it possible to triangulate them.

\subsection{Other Tools for Measuring Overtourism}

The studies that use the Internet and social networks for the measurement of overtourism collect and analyse a large amount of information (Big Data) provided by tourists and residents, using user-generated content.

The research that uses the Internet and/or social networks to analyse tourists' opinions has the main objective of assessing their satisfaction with the destination visited. AlonsoAlmeida et al. [22] analyse the opinions of Chinese tourists visiting Barcelona through sentimental analysis using LIWC and Gephi programs. McKinsey and WTTC [7] construct an indicator of the dissatisfaction of tourists to 68 cities based on the negative opinions expressed by them on TripAdvisor. In addition, these authors use information from TripAdvisor to create a concentration index and a historical site prevalence index. The studies based on the Internet and/or social networks to analyse the opinion of residents seek to ascertain their attitudes towards certain aspects of tourism which affects their territory. Smith et al. [38] analyse the opinions that Budapest residents have shared on Facebook about certain events and carry out sentimental analysis using the Sentione software. Cheung and Li [24], based on the searches that residents in Hong Kong carry out on Google (Google Trends), construct an index to measure their level of irritation with tourism "Google irridex". 
Finally, it is worth mentioning a theoretical modelling study which analyses uncertainty, including the aversion of tourists and residents towards overtourism [45].

\section{A Proposal for Measuring Overtourism}

It can be concluded from the review carried out that the measurement of overtourism is a complex issue that has not yet been resolved in the scientific literature. However, it is an issue that cannot be ignored, since it is inherent to the term itself. Its definition implies the quantification of various aspects of tourist activity: tourists received at a destination, its growth rate and spatial-temporal distribution, impacts on residents' quality of life, and impacts on tourist satisfaction.

Given that overtourism is a complex and multi-faceted phenomenon [8], it is not possible to assess its existence or scope using a single measurement tool. Starting from the key elements of the concept of overtourism and based on the conclusions of the literature review carried out, in Figure 3, we propose the most appropriate type of measurement tool for the quantification of each element.

\section{OVERTOURISM}

\section{MEASURE TOOLS}

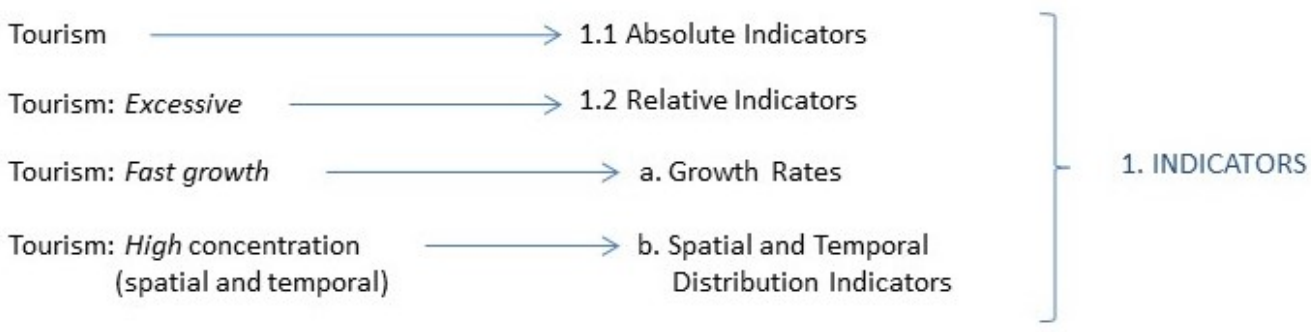

Tourism: Negative impacts on (perceptions):

- Quality of life of Residents

- Tourist satisfaction

2. SURVEYS
3. INTERVIEWS
4. SOCIAL MEDIA

Figure 3. Key elements of overtourism and their measurement tools.

A wide range of tourism indicators can be analysed to quantify the amount of tourism a destination receives, its growth, spatial-temporal concentration, and to establish reference points with which to determine whether it is excessive. Measuring the impact on the quality of life of residents and on tourist satisfaction requires measurement tools that also allow for the quantification of subjective assessments: surveys, interviews, and tools linked to the Internet and social networks. Based on the above, we have drawn up a proposal in four phases to guide the measurement of overtourism in a particular destination (Figure 4).

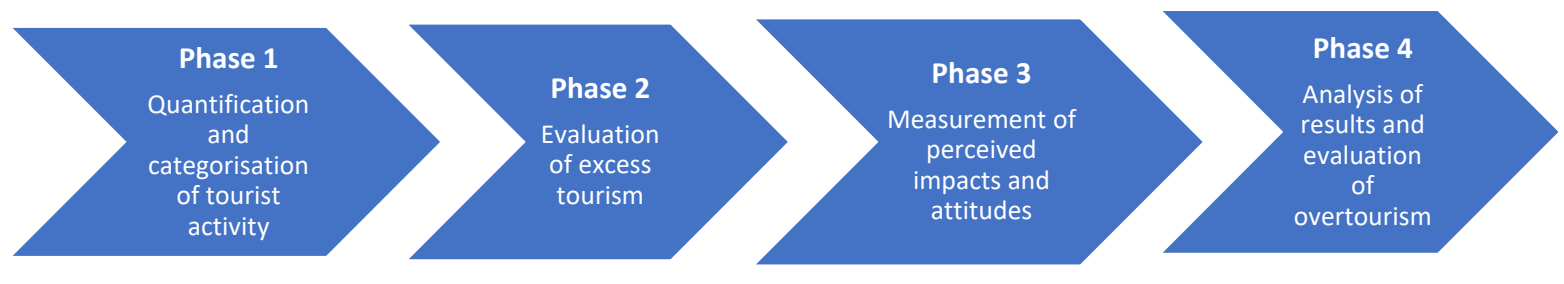

Figure 4. Phases of overtourism measurement.

\subsection{Phase 1. Quantification and Categorisation of Tourist Activity}

There is a wide range of tourism indicators which, although not specifically created for the measurement of overtourism, can be used to explore some of the key aspects of this phenomenon. To this end, many institutions have created systems of tourism indicators that they publish periodically, and have produced guidance for tourist destinations in order 
to monitor sustainable tourism $[46,47]$. However, although they are a starting point, they are not sufficient to quantify the new nuances that the term overtourism implies.

Absolute tourism indicators are useful for defining and scaling the activity, but this is only the first step in order to assess whether tourism in a destination is excessive. First, a set of absolute indicators must be selected to ascertain both tourism demand and supply, as well as the basic economic macroaggregates of the activity in the destination. Given that one of the possible causes of overtourism is the rapid increase in tourists at a given time and place, it is necessary to calculate the growth rates of the absolute indicators selected and to disaggregate the data temporally and spatially. The latter is one of the main shortcomings which we have detected in the review of the literature, since most studies use only average annual data for the whole of the territory under consideration. In order to measure overtourism, seasonality must be quantified since, although the annual figures appear to be sustainable, this may not be the case if the influx of tourists is concentrated in specific periods. Similarly, although, for the territory as a whole, the data do not seem excessive, they may be so if tourists are concentrated in certain areas. Thus, it is essential to have the maximum level of spatial disaggregation in the indicators. In addition, to assess the above figures, it is necessary to break down the data by tourist typology, since the pressure that tourists can exert on the territory and the host society is very different depending on their behaviour. Tourism associated with nightlife tends to impact more negatively on the quality of life of residents than other types of tourism [38].

Nevertheless, it is not possible to establish thresholds with absolute indicators to determine the existence of overtourism, since the amount of tourism that a destination can sustain depends, among other factors, on the size and characteristics of the territory, society, and economy in which it occurs. In this way, in 2019, Bruges received a third of the tourists that arrived in Brussels, but, if these data are relativised taking into account the resident population, Bruges received 11 tourists per resident, while Brussels only three $[48,49]$.

\subsection{Phase 2. Assessment of Excess Tourism}

To assess whether tourism is excessive for a particular destination, absolute tourism indicators must be related to general variables of the territory, society, and economy, i.e., the second step must be to calculate and analyse relative tourism indicators.

Relative indicators can be those of demand, supply, or economic factors, depending on the type of absolute indicator under consideration. In Table 1, the most frequent relative indicators for the measurement of excess tourism were classified with the aim of offering a guide with which to select the most appropriate indicators for each destination. Although there are different possibilities for relativising the absolute indicators of demand and supply, variables related to the size of the resident population or the size of the geographical area where the tourist activity takes place are most commonly used. The former refer to indicators of tourism intensity, which make it possible to approximate the pressure of tourism on the population. The latter are indicators of tourism density, which are mainly used to ascertain the pressure on the territory. The absolute economic indicators are usually relativised using the same indicator applied to the general economy, which is useful in assessing the dependence of the economy of the area on tourism. As with absolute indicators, it is also necessary to calculate the spatial-temporal disaggregation of relative indicators. Assessing the existence of excessive tourism requires the calculation and combined analysis of relative demand, supply, and economic indicators at their different levels of disaggregation.

While establishing thresholds for relative indicators can be useful in guiding the early diagnosis of overtourism, there is no consensus on specific figures. At a theoretical level, much literature has been published on the level of tourism that a destination can withstand, most of it based on the seminal papers by Butler [50] and Doxey [51], but this has not been translated into a set of widely accepted reference points for each of the indicators mentioned. As a starting point, the risk levels estimated by McKinsey and WTTC [7] or by Peeters et al. [8] could be used, but they should be recalculated for each destination and 
specific situation, taking into account its spatial scales, type of tourism, and the fragility of its environment.

\subsection{Phase 3. Measurement of Perceived Impacts and Attitudes towards Tourist Activity}

In addition to establishing thresholds for relative indicators, it is necessary to ascertain the impact of the activity on the quality of life of residents and on tourist satisfaction. The measurement of these impacts requires different tools, as they involve subjective assessments which are not directly perceptible using the abovementioned indicators. Gössling et al. [52] advocate a sociopsychological approach to overtourism.

Although there is extensive literature on the impacts of tourist activity on quality of life (see the Uysal et al. [53] review), quantifying them and assessing the existence of overtourism from them is a complex task. In accordance with social exchange theory [21], the attitudes of residents and tourists towards the sector, and therefore their appreciation of overtourism, are influenced by their perception of the benefits and costs they derive from it. Therefore, once tourism activity in a destination has been quantified and categorised through indicators, it is necessary to ascertain the perceptions of the stakeholders in relation to these impacts, and how these can affect the objective and subjective well-being of residents and the satisfaction of tourists. The review of the literature leads us to propose as the main tools for measuring perceived impacts: surveys, interviews, and tools linked to the Internet and social networks. Figure 5 shows a flow chart in which we have summarised the elements to be considered in order to measure the impacts perceived by residents and tourists and their attitude towards the future of the sector. These elements can be used to guide the design of measurement tools and their adaptation to specific destinations and situations.

If the size and composition of the sample and the questionnaire are appropriate, the surveys will provide sufficient quantitative information to identify perceptions and attitudes and to serve as an early warning mechanism for overtourism. To this end, the questionnaire must combine items on perceptions, attitudes, and opinions. In Table 2, we group the most frequent items to measure these aspects and include references to the studies that have used them. The items which best approximate levels of overtourism are those included in the section on attitudes and behaviour, specifically those which measure: attitudes towards future tourist development (whether or not the desirable limit has been reached and whether or not there is room for further growth), feelings towards tourism (level of annoyance or irritation), and responses (acceptance, avoidance, changes in habits).

The works mentioned in Table 2 may serve as a reference for the design of the questionnaires, but they need to be adapted to the particularities of each destination. One option is to conduct preliminary stakeholder interviews $[18,30]$. In addition, as social exchange theory requires, the results of the surveys of residents should be segmented according to the factors that determine the level of benefits and costs they obtain from the sector: community attachment, proximity of the place of residence to the tourist centres, or the relationship with this activity. Thus, for instance, in Barcelona, the opinion of $61.3 \%$ of residents is that the admissible limit of tourists has been reached, while this percentage increases to $84.1 \%$ in the most touristy neighbourhoods [11]. Likewise, following Namberger et al. [23], we recommend including a section linked to possible fields of conflict in order to detect the specific aspects of tourist activity which cause negative impacts. 


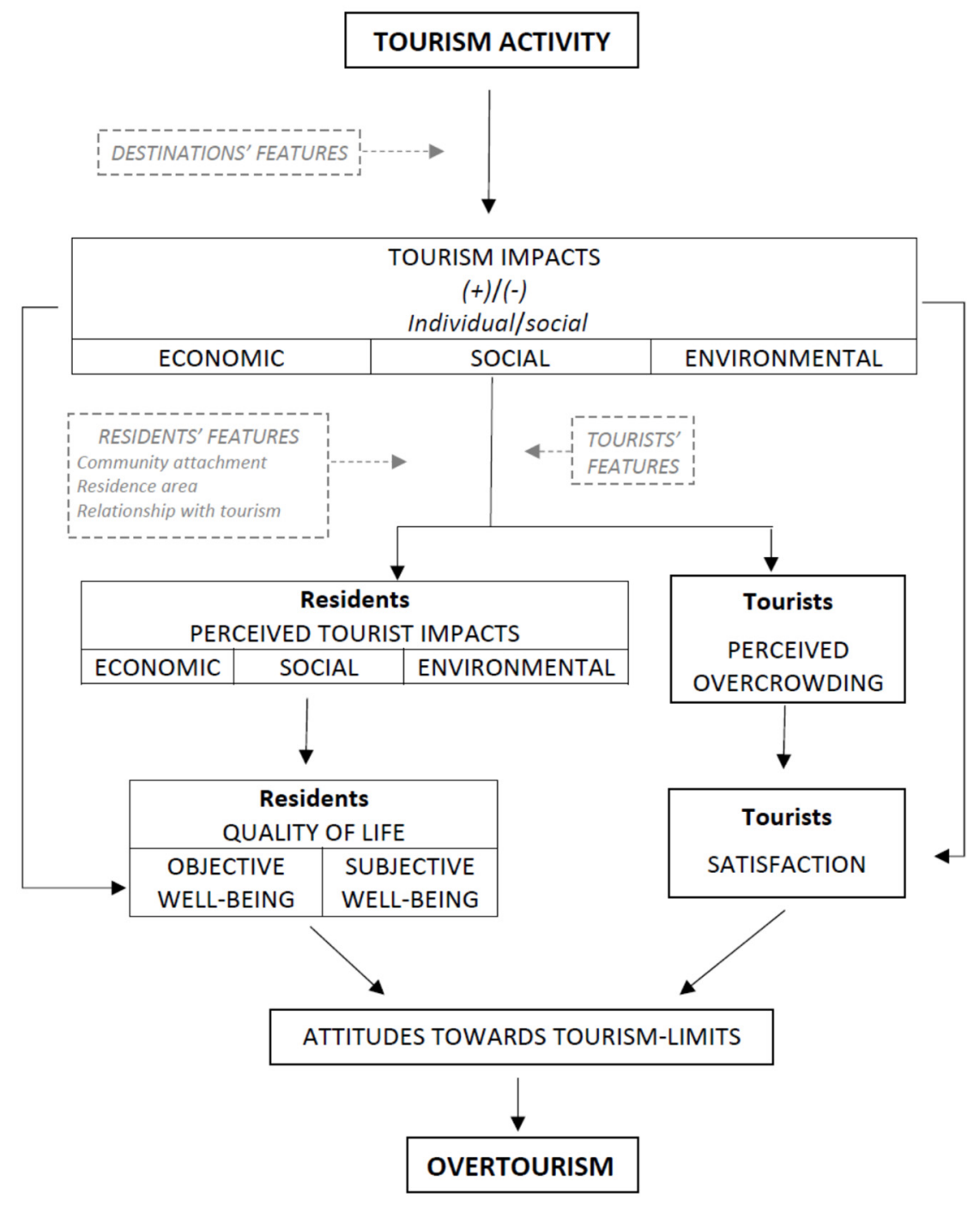

Figure 5. Measuring overtourism: perceived impacts and attitude towards the future of the sector.

Additionally, measurement tools linked to the Internet and social networks allow a large amount of information to be easily collected, often in real time and for very specific locations. A larger sample can be covered and information compiled at different points in time. Therefore, it could become an effective source for periodically monitoring the development of the perception of the impacts of tourism by both tourists and residents. The main problem to date has been the processing of such voluminous information, but specific software and Big Data analysis tools are increasingly being developed to make this possible. In addition to the creation of tools linked to the Internet and specific social networks for each destination, general networks, such as TripAdvisor, Booking, or Google Trends, can be used to ascertain both tourist satisfaction and residents' attitudes. From portals such as TripAdvisor or Booking, in which the client leaves their quantitative and qualitative assessments, tourist satisfaction indicators can be obtained. From Google Trends, statistics on the most searched-for terms can be monitored, and problems detected by tourists and/or residents can be identified. The analysis of comments on Facebook, Twitter, or Instagram [54] can also be used.

\subsection{Phase 4. Analysis of Results and Assessment of the Overtourism Situation}

Finally, to assess the existence and scope of overtourism, once the measurement tools have been adapted, they must be analysed. Although the establishment of thresholds for indicators may be useful, it is not sufficient. Each situation is unique and, therefore, the 
assessment of overtourism requires detailed knowledge of each destination. In this sense, the key lies in the combination of quantitative tools with others of a qualitative nature.

Interviews allow in-depth and qualified information to be obtained about the opinion of the most significant stakeholders in a particular territory. Therefore, it is advisable to use their assessments, both to adapt the quantitative tools to the particularities of each destination and to interpret the information obtained from them. To this end, individual interviews and discussion groups can be a useful tool for reaching a consensus on the limits of tourism activity. Interviews should be carried out based on a validated protocol; the one used in Koens et al. [2] could serve as a guide. As Akbulut and Ekin [29] suggest, it may be relevant to include in the interviews and/or surveys a final question in which the participant assesses the overall situation of the tourist activity. These authors have designed a seven-point scale spectrum ranging from sustainable tourism to overtourism. In Figure 6, we adapted the scale to include responsible, rather than sustainable, tourism. The concept of responsible tourism is broader than the idea of sustainable tourism, as it focuses not only on the pillars of sustainability, but also on its practical implementation [6,55]. In fact, the existence of overtourism reflects the incorrect practical implementation of the ideas of sustainable tourism, so it is more accurate to consider responsible tourism at the opposite end of the spectrum.

\begin{tabular}{|c|c|c|c|c|c|c|}
\hline \multicolumn{5}{|c|}{ Overtourism } & \multicolumn{2}{|c|}{$\begin{array}{r}\text { Responsible } \\
\text { Tourism }\end{array}$} \\
\hline 1 & 2 & 3 & 4 & 5 & 6 & 7 \\
\hline
\end{tabular}

Figure 6. Holistic tourism development spectrum. Source: Adapted from Akbulut and Ekin [29].

Proper management of overtourism requires that all the aforementioned be periodically monitored and included in the new governance models of tourist destinations since tourism is an economic activity that can promote institutional quality [56]. Therefore, it would be advisable to establish links between the proposed model for measuring overtourism and smart cities [57].

\section{Conclusions}

This research has focused on the measurement of overtourism, carrying out a review of the literature using the mapping review method. Overtourism has become a fashionable topic in scientific literature with an exponential growth in publications in recent years. However, despite the fact that the definition of the term implies the need to quantify certain aspects of tourist activity, most of the works analysed either do not include any element of measurement, or do so only partially and indirectly. For this reason, there are serious deficiencies in what has been measured regarding this phenomenon.

Overtourism is a complex, multidisciplinary, and multidimensional phenomenon, which manifests itself in a variety of ways in different destinations, especially cities, making it impossible to establish single-size recipes for its measurement. For this reason, in order to carry out rigorous analyses and correctly manage the problems arising from overtourism, it is necessary to select the most appropriate measurement tools to quantify each of the dimensions of overtourism, and to establish some kind of threshold to aid early diagnosis.

The conclusions drawn from the literature review carried out have led us to propose guidelines for measuring overtourism that combine absolute and relative indicators, surveys, interviews, and tools linked to the Internet and social networks; this will allow us to move along to that yet to be measured.

The first step is to scale and categorise tourist activity, using absolute indicators as the most appropriate tool. Then, in order to obtain initial reference points from which to explore the presence of excessive tourism, these absolute indicators must be put into perspective in the context of the variables of the territory, society, and economy. Given that overtourism has a negative impact on the quality of life of residents and on tourist 
satisfaction, it is necessary to use measurement factors which explore subjective aspects: surveys, tools linked to the Internet and social networks, and interviews. The first two allow for a great deal of information to be obtained from both residents and tourists. Through interviews, it is possible to obtain the qualitative information necessary to adapt the previous sources of measurement to the reality of each destination, establish reference points or thresholds, and enable proper interpretation of the results.

A rigorous quantification of overtourism requires that the measurement tools be created with broad levels of disaggregation. The indicators chosen must be able to be broken down temporally and spatially, and take into account the various types of tourism that occur in a particular destination. The results of surveys, interviews, and tools linked to social networks must be able to be segmented according to the elements which may affect the perception of the costs and benefits that tourism may have on stakeholders (area of residence, feelings towards the destination, relationship with tourism, among others). The lack of disaggregation is one of the main shortcomings detected in the papers reviewed.

As a future line of research, we propose following the guidelines put forward in this paper to carry out measurements in specific destinations and, based on these, to establish thresholds which can serve as a reference for assessing the presence and extent of overtourism. In addition, the current context of undertourism caused by COVID-19 brings to the fore a line of research into the measurement of the phenomenon which is the opposite of that discussed in this paper. A proper measurement of both overtourism and undertourism is essential to formulate effective land-use policies by guiding policy makers. In this vein, as a future line of research, it would be advisable to explore the synergies that can be established between the technology linked to smart cities and the monitoring of overtourism (or undertourism).

Supplementary Materials: The following are available online at https:/ /www.mdpi.com/article/10 $.3390 /$ land10090889/s1, Figure S1: Features of the sample of papers on overtourism.

Author Contributions: Conceptualization, E.M.B. and R.Y.; Methodology, E.M.B. and R.Y.; Software, E.M.B. and R.Y.; Validation, E.M.B. and R.Y.; Formal Analysis, E.M.B. and R.Y.; Investigation, E.M.B. and R.Y.; Resources, E.M.B. and R.Y.; Data Curation, E.M.B. and R.Y.; Writing-Original Draft Preparation, E.M.B. and R.Y.; Writing—Review and Editing, E.M.B. and R.Y. All authors have read and agreed to the published version of the manuscript.

Funding: This research received no external funding.

Institutional Review Board Statement: Not applicable.

Informed Consent Statement: Not applicable.

Data Availability Statement: Not applicable.

Acknowledgments: The research is partially supported by the Research Groups of Research in Applied Economics (SEJ132, SEJ 258. Plan Andaluz de Investigación, Junta de Andalucía, Spain). The Authors would like to express their appreciation to the anonymous reviewers for their very helpful comments provided during the revision of the paper.

Conflicts of Interest: The authors declare no conflict of interest. The funders had no role in the design of the study; in the collection, analyses, or interpretation of data; in the writing of the manuscript, or in the decision to publish the results.

\section{References}

1. United Nations World Tourism Organisation (UNWTO). Overtourism: Understanding and Managing Urban. Tourism Growth Beyond Perceptions; United Nations World Tourism Organisation (UNWTO): Madrid, Spain, 2018.

2. Koens, K.; Postma, A.; Papp, B. Is overtourism overused? Understanding the impact of tourism in a city context. Sustainability 2018, 10, 4384. [CrossRef]

3. Hjalager, A.-M. Land-use conflicts in coastal tourism and the quest for governance innovations. Land Use Policy 2020, $94,104566$. [CrossRef]

4. Capocchi, A.; Vallone, C.; Amaduzzi, A.; Pierotti, M. Is "overtourism" a new issue in tourism development or just a new term for an already known phenomenon? Curr. Issues Tour. 2019, 23, 2235-2239. [CrossRef] 
5. Jiménez-García, M.; Ruiz-Chico, J.; Peña-Sánchez, A.R. Landscape and tourism: Evolution of research topics. Land 2020,9 , 488. [CrossRef]

6. Mihalic, T. Conceptualizing overtourism: A sustainability approach. Ann. Tour. Res. 2020, 84, 103025. [CrossRef]

7. World Travel and Tourism Council. Coping with Success: Managing Overcrowding in Tourist Destinations; McKinsey and Company: New York, NY, USA, 2017.

8. Peeters, P.M.; Gössling, S.; Klijs, J.; Milano, C.; Novelli, M.; Dijkmans, C.H.S.; Eijgelaar, E.; Hartman, S.; Heslinga, J.; Isaac, R.; et al. Research for TRAN Committee-Overtourism: Impact and Possible Policy Responses; European Parliament Structural and Cohesion Policies, Transport and Tourism: Brussels, Belgium, 2018.

9. Spanish Statistics National Institute. Hotel Occupancy Survey 2020. Available online: https://www.ine.es/dynt3/inebase/en/ index.htm?padre $=6778 \&$ capsel $=6780$ (accessed on 13 August 2021).

10. Papathanassis, A. Over-tourism and anti-tourist sentiment: An exploratory analysis and discussion. Ovidius Univ. Ann. Econ. Sci. Ser. 2017, 17, 288-293.

11. Turisme a Barcelona. Tourism Activity Report 2019. Ayuntamiento de Barcelona. 2020. Available online: https://www. observatoriturisme.barcelona/sites/default/files/Capsula_3_IAT2019_0.pdf (accessed on 15 August 2021).

12. Organisation for Economic Co-operation and Development (OECD). OECD Policy Responses to Coronavirus (COVID-19), Rebuilding Tourism for the Future: Response and Recovery. 2020. Available online: http:/ /www.oecd.org/coronavirus/policyresponses/rebuilding-tourism-for-the-future-covid-19-policy-responses-and-recovery-bced9859/ (accessed on 21 April 2021).

13. Grant, M.J.; Booth, A. A typology of reviews: An analysis of 14 review types and associated methodologies. Health Inf. Libr. J. 2009, 26, 91-108. [CrossRef] [PubMed]

14. Cruz, M.S.; Zaragoza, M.P.P. Analysis of the accommodation density in coastal tourism areas of insular destinations from the perspective of overtourism. Sustainability 2019, 11, 3031. [CrossRef]

15. Baños, C.; Hernández, M.; Rico, A.; Olcina, J. The hydrosocial cycle in coastal tourist destinations in Alicante, Spain: Increasing resilience to drought. Sustainability 2019, 11, 4494. [CrossRef]

16. Carballo, R.R.; León, C.J.; Carballo, M.M. Fighting overtourism in Lanzarote (Spain). Worldw. Hosp. Tour. Themes 2019, 11, 506-515. [CrossRef]

17. Kagermeier, A.; Erdmenger, E. Overtourismus. Z. Tour. 2019, 11, 65-98. [CrossRef]

18. Martín, J.M.M.; Martínez, J.M.G.; Fernández, J.A.S. An analysis of the factors behind the citizen's attitude of rejection towards tourism in a context of overtourism and economic dependence on this activity. Sustainability 2018, 10, 2851. [CrossRef]

19. Kuščer, K.; Mihalič, T. Residents' attitudes towards overtourism from the perspective of tourism impacts and cooperation-The case of Ljubljana. Sustainability 2019, 11, 1823. [CrossRef]

20. Cardoso, C.; Silva, M. Residents' perceptions and attitudes towards future tourism development. Worldw. Hosp. Tour. Themes 2018, 10, 688-697. [CrossRef]

21. Gutiérrez-Taño, D.; Garau-Vadell, J.B.; Díaz-Armas, R.J. The influence of knowledge on residents' perceptions of the impacts of overtourism in P2P accommodation rental. Sustainability 2019, 11, 1043. [CrossRef]

22. Alonso-Almeida, M.-D.; Borrajo-Millán, F.; Yi, L. Are social media data pushing overtourism? The case of Barcelona and Chinese tourists. Sustainability 2019, 11, 3356. [CrossRef]

23. Namberger, P.; Jackisch, S.; Schmude, J.; Karl, M. Overcrowding, overtourism and local level disturbance: How much can Munich handle? Tour. Plan. Dev. 2019, 16, 452-472. [CrossRef]

24. Cheung, K.S.; Li, L.-H. Understanding visitor-resident relations in overtourism: Developing resilience for sustainable tourism. J. Sustain. Tour. 2019, 27, 1197-1216. [CrossRef]

25. Canavan, B. Tourism stakeholder exclusion and conflict in a small island. Leis. Stud. 2016, 1-14. [CrossRef]

26. Gürsoy, T. Beauty and the beast: A fairy tale of tourismphobia. Tour. Plan. Dev. 2019, 16, 434-451. [CrossRef]

27. Maingi, S.W. Sustainable tourism certification, local governance and management in dealing with overtourism in East Africa. Worldw. Hosp. Tour. Themes 2019, 11, 532-551. [CrossRef]

28. Zmyślony, P.; Kowalczyk-Anioł, J. Urban tourism hypertrophy: Who should deal with it? The case of Krakow (Poland). Int. J. Tour. Cities 2019, 5, 247-269. [CrossRef]

29. Akbulut, O.; Ekin, Y. Perceptions of tourism-related non-governmental organization (NGO) managers in Antalya. Worldw. Hosp. Tour. Themes 2019, 11, 594-610. [CrossRef]

30. Šegota, T.; Mihalic, T.; Kuščer, K. The impact of residents' informedness and involvement on their perceptions of tourism impacts: The case of Bled. J. Destin. Mark. Manag. 2017, 6, 196-206. [CrossRef]

31. Sarantakou, E.; Terkenli, T.S. Non-institutionalized forms of tourism accommodation and overtourism impacts on the landscape: The case of Santorini, Greece. Tour. Plan. Dev. 2019, 16, 411-433. [CrossRef]

32. Del Chiappa, G.; Atzeni, M.; Ghasemi, V. Community-based collaborative tourism planning in islands: A cluster analysis in the context of Costa Smeralda. J. Destin. Mark. Manag. 2018, 8, 41-48. [CrossRef]

33. Muler Gonzalez, V.; Coromina, L.; Galí, N. Overtourism: Residents' perceptions of tourism impact as an indicator of resident social carrying capacity-Case study of a Spanish heritage town. Tour. Rev. 2018, 73, 277-296. [CrossRef]

34. Jacobsen, J.; Iversen, N.; Hem, L. Perceived crowding and tourism: Promotion and prevention reactions. Int. J. Bus. Manag. 2018, 2, 47-51. 
35. Jacobsen, J.K.S.; Iversen, N.M.; Hem, L.E. Hotspot crowding and over-tourism: Antecedents of destination attractiveness. Ann. Tour. Res. 2019, 76, 53-66. [CrossRef]

36. Liu, A.; Ma, E. Travel during holidays in China: Crowding's impacts on tourists' positive and negative affect and satisfactions. J. Hosp. Tour. Manag. 2019, 41, 60-68. [CrossRef]

37. Pinke-Sziva, I.; Smith, M.; Olt, G.; Berezvai, Z. Overtourism and the night-time economy: A case study of Budapest. Int. J. Tour. Cities 2019, 5, 1-16. [CrossRef]

38. Smith, M.K.; Sziva, I.P.; Olt, G. Overtourism and resident resistance in Budapest. Tour. Plan. Dev. 2019, 16, 376-392. [CrossRef]

39. Milano, C.; De Lleida, O.U. Overtourism, malestar social y turismofobia. Un debate controvertido. PASOS Rev. Tur. Patrim. Cult. 2018, 18, 551-564. [CrossRef]

40. Dodds, R.; Holmes, M.R. Beach tourists; what factors satisfy them and drive them to return. Ocean. Coast. Manag. 2019, 168, 158-166. [CrossRef]

41. Milano, C.; Novelli, M.; Cheer, J.M. Overtourism and degrowth: A social movements perspective. J. Sustain. Tour. 2019, 27, 1857-1875. [CrossRef]

42. Cheer, J.M.; Milano, C.; Novelli, M. Tourism and community resilience in the Anthropocene: Accentuating temporal overtourism. J. Sustain. Tour. 2018, 27, 554-572. [CrossRef]

43. Mhanna, R.; Blake, A.; Jones, I. Spreading tourists around host countries of mega sport events. Worldw. Hosp. Tour. Themes 2019, 11, 611-626. [CrossRef]

44. Jørgensen, M.T.; McKercher, B. Sustainability and integration-The principal challenges to tourism and tourism research. J. Travel Tour. Mark. 2019, 36, 905-916. [CrossRef]

45. Marsiglio, S. Uncertainty, crowding aversion and tourism aversion in tourism destinations. Tour. Econ. 2016, 22, 111-123. [CrossRef]

46. European Commission. The European Tourism Indicator System: ETIS toolkit for Sustainable Destination Management; Publications Office of the European Union: Luxembourg, 2016.

47. United Nations World Tourism Organisation (UNWTO). Indicators of Sustainable Development for Tourism Destinations: A Guidebook; United Nations World Tourism Organisation (UNWTO): Madrid, Spain, 2004.

48. Directorate-General for Statistics. Arrivals and Overnight Data in Touristic Regions of Flanders. 2021. Available online: https: / toerismevlaanderen.be/tourism-figures-2020-xl\#Dashboard (accessed on 13 August 2021).

49. Eurostat. Population on 1 January by Age Groups and Sex-Cities and Greater Cities. 2021. Available online: https://ec.europa. eu/eurostat/databrowser/view/urb_cpop1/default/table?lang=en (accessed on 13 August 2021).

50. Butler, R.W. The concept of a tourist area cycle of evolution: Implications for management of resources. Can. Geogr. 1980, $24,5-12$. [CrossRef]

51. Doxey, G.V. A causation theory of visitor-resident irritants: Methodology and research inferences. In Proceedings of the Sixth Annual Conference of the Travel and Tourism Research Associations, San Diego, CA, USA, 8-11 September 1975; pp. 195-198.

52. Gössling, S.; McCabe, S.; Chen, N.C. A socio-psychological conceptualisation of overtourism. Ann. Tour. Res. 2020, 84, 102976. [CrossRef] [PubMed]

53. Uysal, M.; Sirgy, M.J.; Woo, E.; Kim, H. Quality of life (QOL) and well-being research in tourism. Tour. Manag. 2016, 53, $244-261$. [CrossRef]

54. Palazzo, M.; Vollero, A.; Vitale, P.; Siano, A. Urban and rural destinations on Instagram: Exploring the influencers' role in \#sustainabletourism. Land Use Policy 2021, 100, 104915.

55. Terkenli, T.S.; Skowronek, E.; Georgoula, V. Landscape and tourism: European expert views on an intricate relationship. Land 2021, 10, 327. [CrossRef]

56. Buitrago, E.M.; Caraballo, M.A. Exploring the links between tourism and quality of institutions. Cuad. De Tur. 2019, 43, 215-247. [CrossRef]

57. Santos, A., Jr.; Almeida-García, F.; Morgado, P.; Mendes-Filho, L. Residents' quality of life in smart tourism destinations: A theoretical approach. Sustainability 2020, 12, 8445. [CrossRef] 